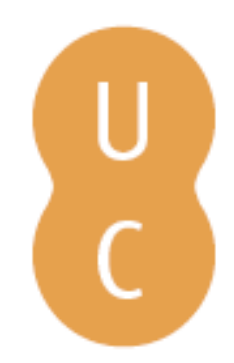

\title{
pommalina
}

\section{MALDI-MSI: a new tool for metab olite analysis in forensic science}

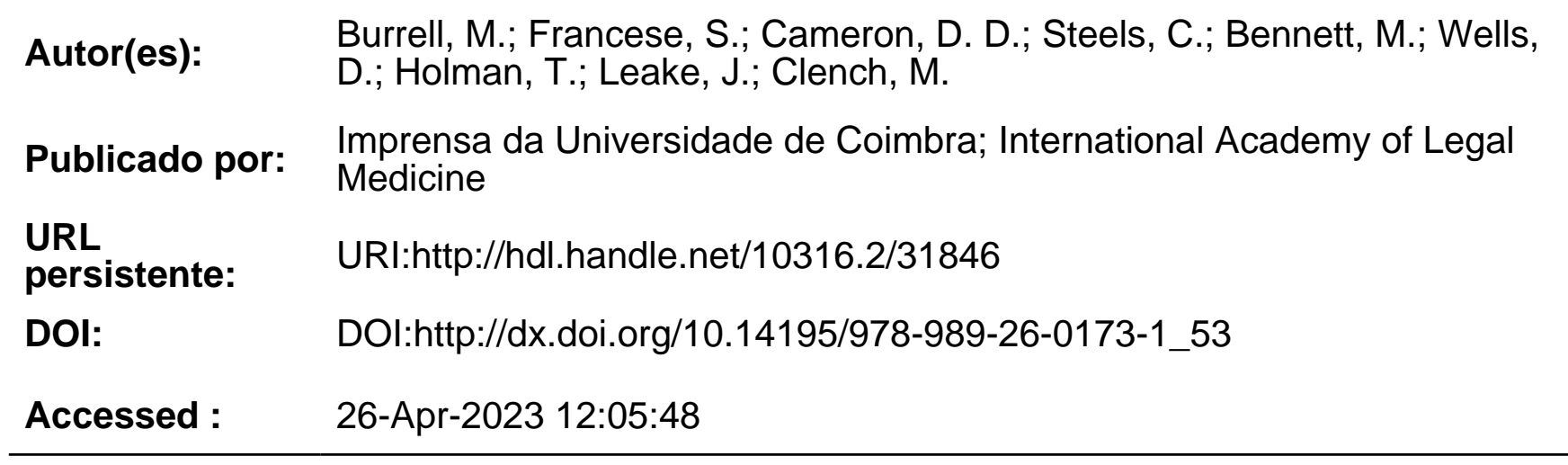

A navegação consulta e descarregamento dos títulos inseridos nas Bibliotecas Digitais UC Digitalis, UC Pombalina e UC Impactum, pressupõem a aceitação plena e sem reservas dos Termos e Condições de Uso destas Bibliotecas Digitais, disponíveis em https://digitalis.uc.pt/pt-pt/termos.

Conforme exposto nos referidos Termos e Condições de Uso, o descarregamento de títulos de acesso restrito requer uma licença válida de autorização devendo o utilizador aceder ao(s) documento(s) a partir de um endereço de IP da instituição detentora da supramencionada licença.

Ao utilizador é apenas permitido o descarregamento para uso pessoal, pelo que o emprego do(s) título(s) descarregado(s) para outro fim, designadamente comercial, carece de autorização do respetivo autor ou editor da obra.

Na medida em que todas as obras da UC Digitalis se encontram protegidas pelo Código do Direito de Autor e Direitos Conexos e demais legislação aplicável, toda a cópia, parcial ou total, deste documento, nos casos em que é legalmente admitida, deverá conter ou fazer-se acompanhar por este aviso.

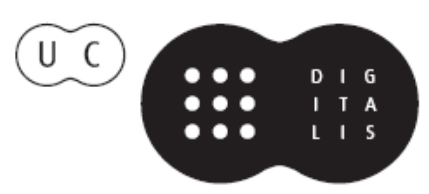




\section{Duarte Nuno Vieira Anthony Busuttil \\ Denis Cusack • Philip Beth}
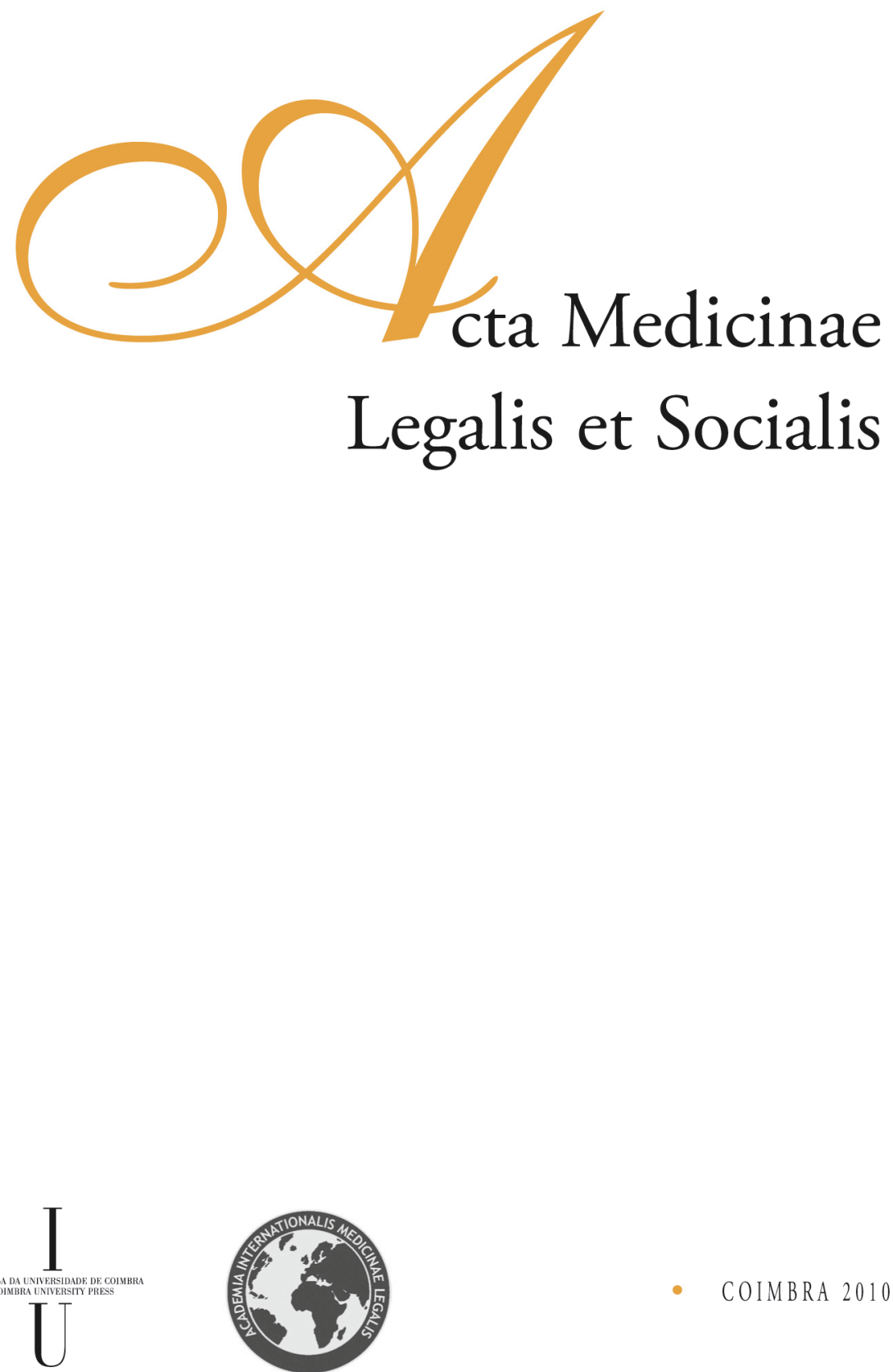
M. Burrell ${ }^{1}$, S. Francese ${ }^{2}$, D. D. Cameron ${ }^{1}$, C. Steels ${ }^{1}$, M. Bennett ${ }^{3}$,

D. Wells ${ }^{3}$, T. Holman ${ }^{3}$, J. Leake ${ }^{1}$, M. Clench ${ }^{2}$

${ }^{1}$ Department of Animal and Plant Sciences, University of Sheffield, UK

${ }^{2}$ Biomedical Research Centre, Sheffield Hallam University, UK

${ }^{3}$ Centre for Plant Integrative Biology, School of Biosciences, University of Nottingham, UK

\title{
MALDI-MSI - A NEW TOOL FOR METABOLITE ANALYSIS IN FORENSIC SCIENCE.
}

\begin{abstract}
Imaging Matrix Assisted Laser Desorption Mass Spectrometry provides a new powerful tool to analyse the distribution of metabolites within plant or animal tissues and to compare with an untargeted approach different tissues or samples from different organisms. Metabolites may be mapped at a single cell resolution and the technique may be used to resolve the differences between two samples of tissue.
\end{abstract}

\section{Introduction}

The aim of the work reported in this paper was to develop a method, which would allow the cellular distribution of metabolites in plant tissues to be determined. Metabolic fingerprinting and profiling is an emerging technique and has recently been used to identify ecologically important genes and traits ${ }^{1}$. In a recent study of Arabidopsis petraea it was used to identify that individual plants of this species from different countries were significantly different. Plants from the same country were more closely related ${ }^{2}$.

To understand the control of metabolism one needs to determine the amounts of metabolites present in the cell and the amounts of enzyme present ${ }^{3}$. Many recent studies with techniques such as immunolocalisation and in situ hybridisation have demonstrated that cells from the same tissue can have different patterns of gene expression $^{4,5}$. With plant material the task of measuring metabolites is very large since there are in excess of 100,000 metabolites that can occur ${ }^{6,7}$. Thus homogenisation of a whole tissue can potentially reduce a high concentration of a compound present in a few cells to a level that is not detectable.

Matrix Assisted Laser Desorption Ionisation Mass Spectrometry Imaging (MALDIMSI) offers potential as an approach to both analyse in a targeted way the distribution of metabolites across tissues, and to profile in an untargeted way individual samples. MALDI is a very versatile technique since it will ionise compounds from a wide range of chemical classes ${ }^{8}$. MALDI-MSI is a derivation of this technique where the sample on the MALDI stage is moved on the $\mathrm{x} / \mathrm{y}$ axis and each sample position is assayed? Therefore by recording the mass spectrum at each position a two dimensional image of the metabolic profile of a sample may be obtained. The diameter of the laser in modern 
mass spectrometers is in the order of $100 \mu \mathrm{m}$ or less. Thus at a spatial resolution of 100 $\mu \mathrm{m}$ it is possible to obtain a mass profile of those compounds present on the surface of a tissue. With modern high resolution mass spectrometers and careful selection of the matrix MALDI has the potential to allow analysis of metabolites and avoid too many interfering peaks.

In this paper we have examined the usefulness of the method for metabolic profiling of different plant tissues. It has also been used to measure the distribution of drugs applied to skin and the metabolism of these drugs ${ }^{10}$

\section{Materials and Methods}

Wheat (Triticum aestivum L. var Axona) plants were grown as described previously ${ }^{11}$. Orchid material Goodyera repens was collected from the wild and maintained in a growth room. Longitudinal sections $(60 \mu \mathrm{m}$ thick) were prepared, in a Leica Cryostat, from roots flash frozen in liquid nitrogen. Arabidopsis thaliana seedlings were grown as described previously ${ }^{12}$ and roots taken from $7 \mathrm{~d}$ old seedlings. Sections were freeze dried prior to coating with matrix. Sections were coated using an airspray with a solution of $25 \mathrm{mg} \mathrm{ml}^{-1} \alpha$-cyano-4-hydroxycinnamic acid in methanol containing $0.1 \%$ (v/v) trifluoracetic acid.

MALDI MS spectra were acquired with an Applied Biosystems/MDS Sciex hybrid quadrupole time-of-flight (Q-Star Pulsar-i), fitted with an orthogonal MALDI ion source and an Nd:YAG laser. The instrument conditions were Repetition rate: $1000 \mathrm{~Hz}$, Laser energy $20 \%(2.3 \mu \mathrm{J})$ and analysis time of 5 seconds per position. Images were created from the Analyst data files with Biomap 3.7.5.

Principal component analysis of mass profiles in images was performed using the program SimcaP supplied by UMetrics.

\section{Results and discussion}

An analysis of sections from wheat endosperm is presented in Fig 1. Some 40,000 masses were detected in these sections and taking into account that adducts of sodium and potassium as well as the protonated ion can occur then this figure could represent about 13,000 metabolites. It can be seen that the mass of 175 for arginine is not evenly distributed across the section at any stage of development (figure 1a). Thus an analysis involving extracting the whole grain would grossly under estimate the concentration present in certain parts. The mass of 175 was shown to be mainly arginine by a MS/MS analysis (data not shown). The distribution of arginine (175) is similar to the distribution of ornithine (133) but not sucrose (343) and aspartate (134) (figure $1 \mathrm{~b}$ ). Arginine is synthesized in the ornithine arginine cycle. The images therefore suggest that the cycle is operating in the seeds rather than representing just an accumulation of the arginine.

As demonstrated by Burrell et al. $2007^{9}$ solution of less than $1 \mu \mathrm{g} \mathrm{ml} \mathrm{m}^{-1}$ can be detected. This is equivalent to detecting approximately $1.2 \mathrm{pg}$ of compound if it is all present in the area covered by the laser during one pulse. Several researchers have 
developed methods to map metabolites in tissues ${ }^{13-15}$. These methods can be very sensitive and where fluorescence is involved certainly may be more sensitive than MALDI-MSI. However a direct comparison of the sensitivity of different methods has not been undertaken to date. MALDI-MSI offers two benefits as a mode of analysis. First it simultaneously measures many compounds and secondly it does not depend on chemical class it only requires the compound to become charged.

The diameter of the laser is approximately $100 \mu \mathrm{m}$. It was of interest to determine whether the resolution of the images could approach the size of cells. Mycorrhizal roots (symbiotic interactions between plant roots and fungi where the plant exchanges carbon for mineral nutrients from the fungus partner) were chosen since they have cells some of which approach the size of the laser and one would expect the metabolism of fungal infected cells to differ from the host plant uninfected cells. It is clear from figure 2 that mass 184 is specifically localized to certain cells thus demonstrating the method is sensitive for near cellular resolution. The latest software for MALDI-MSI allows the horizontal resolution to be decreased below the diameter of the laser.

MALDI-MSI provides a method to achieve untargeted analysis of metabolites. With many thousands of masses detected one needs a method to separate those masses which are evenly distributed from those that are localized in areas. A PCA analysis (figure 3) of the data used to provide the image in figure 2 provides a method of identifying these masses. Mass 184 is well separated from most masses and from sucrose identifies as the potassium adduct (381). Similarly this approach may be used to determine whether two samples are from the same individual or species. Figure 4 shows an analysis of the surface of two plant roots from the species Arabidopsis thaliana. Each laser position used to acquire the image has been treated as a separate sample. It is clear that the wild type and putative mutant roots are different and that there is variation across the surface of the root.

\section{Conclusions}

MALDI-MSI provides a powerful targeted or untargeted method of analyzing small molecules such as endogenous metabolites or exogenously applied compounds. Sample preparation is simple and analysis time is rapid. The method can be used with many different tissues. It can be used to identify the presence of known compounds and associated metabolites and to identify where in a sample metabolism is occurring. Alternatively it may be used to identify whether two samples are from the same individual.

\section{References}

1. Mitchell-Olds T. Arabidopsis thaliana and its wild relatives: a model system for ecology and evolution. Trends in Ecology \& Evolution 2001;16:693-700.

2. Davey MP, Burrell MM, Woodward FI, Quick WP. Population-specific metabolic phenotypes of Arabidopsis lyrata ssp petraea. New Phytologist 2008;177:380-388. 
3. Fell D. Understanding the Control of metabolism. In: Snell K, ed. Frontiers in Metabolism. London, Miami: Portland press, 1997 (vol 2).

4. Haritatos E, Ayre BG, Turgeon R. Identification of phloem involved in assimilate loading in leaves by the activity of the galactinol synthase promoter. Plant Physiology 2000;123:929-937.

5. Wittich PE, Vreugdenhil D. Localization of sucrose synthase activity in developing maize kernels by in situ enzyme histochemistry. Journal of Experimental Botany 1998;49:1163-1171.

6. Oksman-Caldentey KM, Inze D. Plant cell factories in the post-genomic era: new ways to produce designer secondary metabolites. Trends in Plant Science 2004;9:433-440.

7. Weckwerth W, Fiehn O. Can we discover novel pathways using metabolomic analysis? Current Opinion in Biotechnology 2002;13:156-160.

8. Karas M, Bachmann D, Bahr U, Hillenkamp F. Matrix-Assisted Ultraviolet-Laser Desorption of Nonvolatile Compounds. International Journal of Mass Spectrometry and Ion Processes 1987;78:53-68.

9. Burrell MM, Earnshaw CJ, Clench MR. Imaging Matrix Assisted Laser Desorption Ionization Mass Spectrometry: a technique to map plant metabolites within tissues at high spatial resolution. Journal of Experimental Botany 2007;58:757-763.

10. Earnshaw CJ, Atkinson SJ, Burrell MM, Clench MR. Matrix Assisted Laser Desorption Ionisation Mass Spectrometric Imaging - Principles and Applications. In: Griffiths WJ, ed. Metabolomics, Metabonomics and Metabolite profiling. London: Royal Society of Chemistry, 2008.

11. Burrell M, Bendall L, Read D, Leake J, Clench M, Earnshaw C. The cellular distribution of metabolites in mycorrhizal Orchid roots measured by Imaging MALDI. Comparative Biochemistry and Physiology a-Molecular \& Integrative Physiology 2007;146:S222-S222.

12. French A, Ubeda-Tomas S, Holman TJ, Bennett MJ, Pridmore T. Quantifying root growth using a new image analysis tool. Plant Physiology 2009;150:1784-1795.

13. Borisjuk L, Walenta S, Rolletschek H, Mueller-Klieser W, Wobus U, Weber H. Spatial analysis of plant metabolism: Sucrose imaging within Vicia faba cotyledons reveals specific developmental patterns. Plant Journal 2002;29:521-530.

14. Borisjuk L, Walenta S, Weber H, Mueller-Klieser W, Wobus U. High-resolution histographical mapping of glucose concentrations in developing cotyledons of Vicia faba in relation to mitotic activity and storage processes: glucose as a possible developmental trigger. Plant Journal 1998;15:583-591.

15. Walenta S, Schroeder T, Mueller-Klieser W. Metabolic mapping with bioluminescence: basic and clinical relevance. Biomolecular Engineering 2002;18:249-262. 

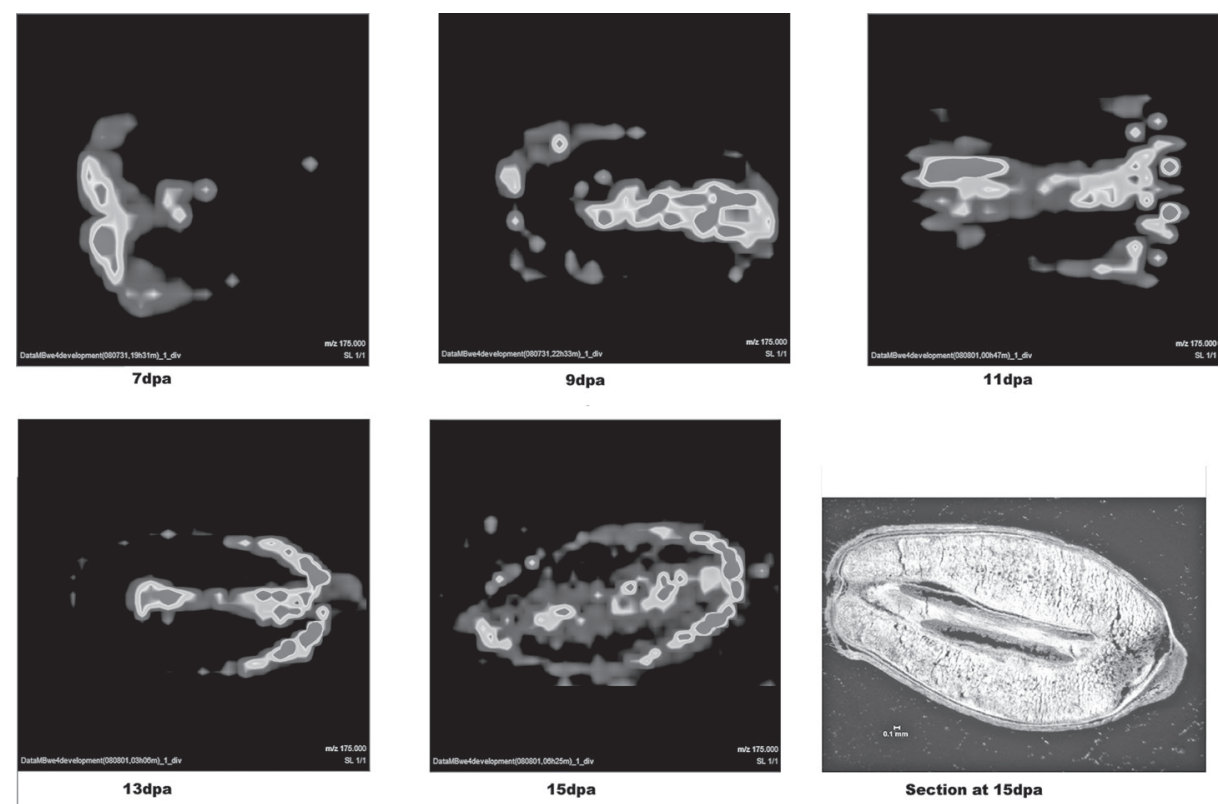

15dpa

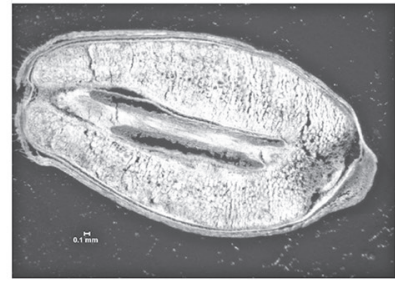

Section at 15dpa
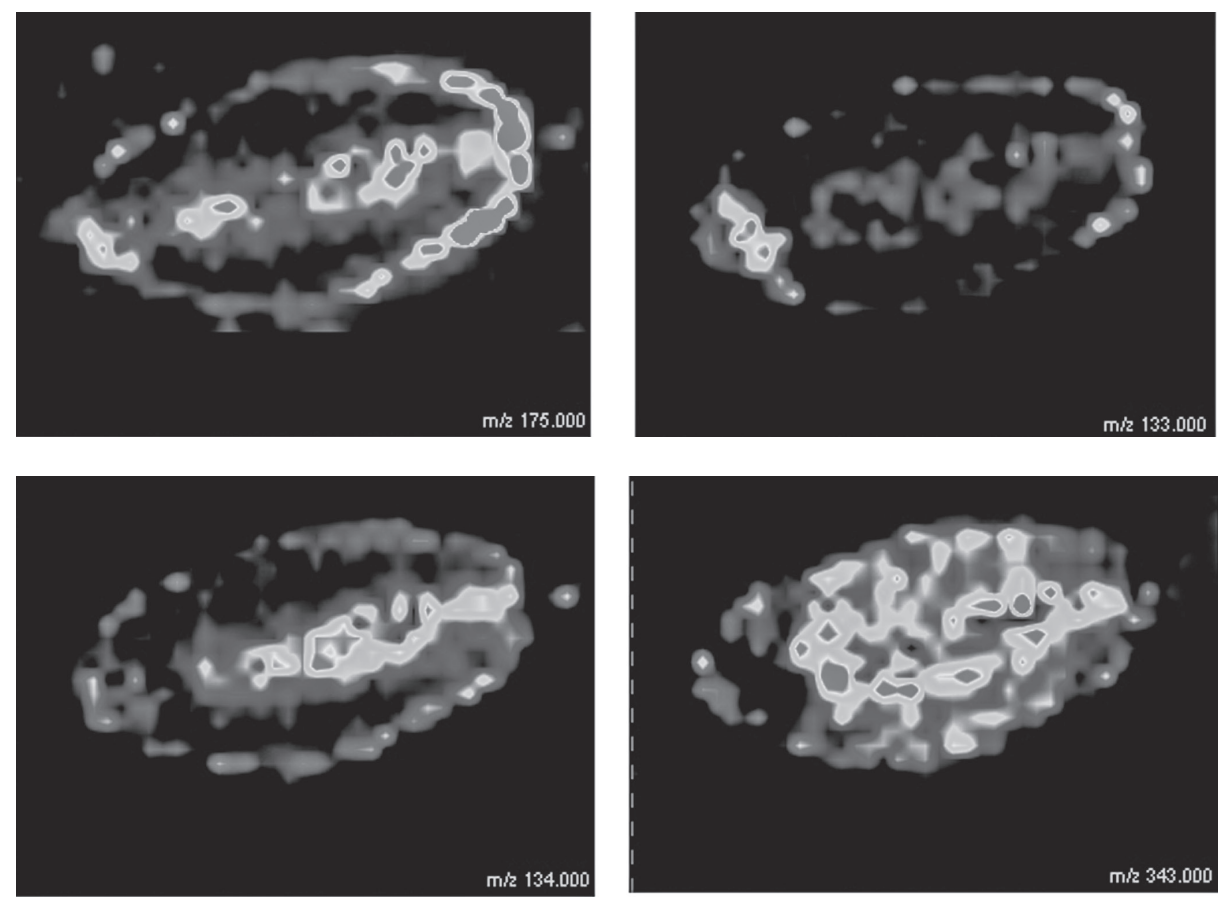

Figure 1 - Distribution of amino acids in developing wheat grains.

A. The distribution of the mass 175 (arginine) during different stages of development

B. The distribution of arginine (175), ornithine (133), members of the ornithine arginine cycle compared with aspartate (134), and sucrose (343) in a section of grain taken 15 days post anthesis. Red indicates a high intensity of signal, blue a low intensity. 


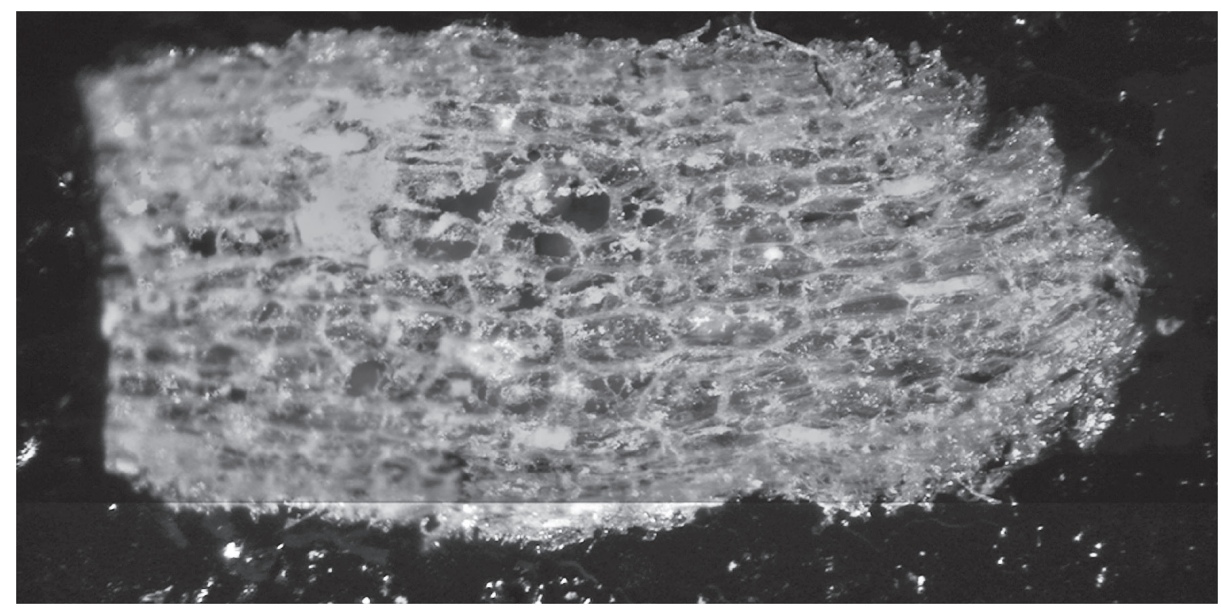

Figure 2 - The cell specific distribution of mass 184 in orchid mycorrhyza roots

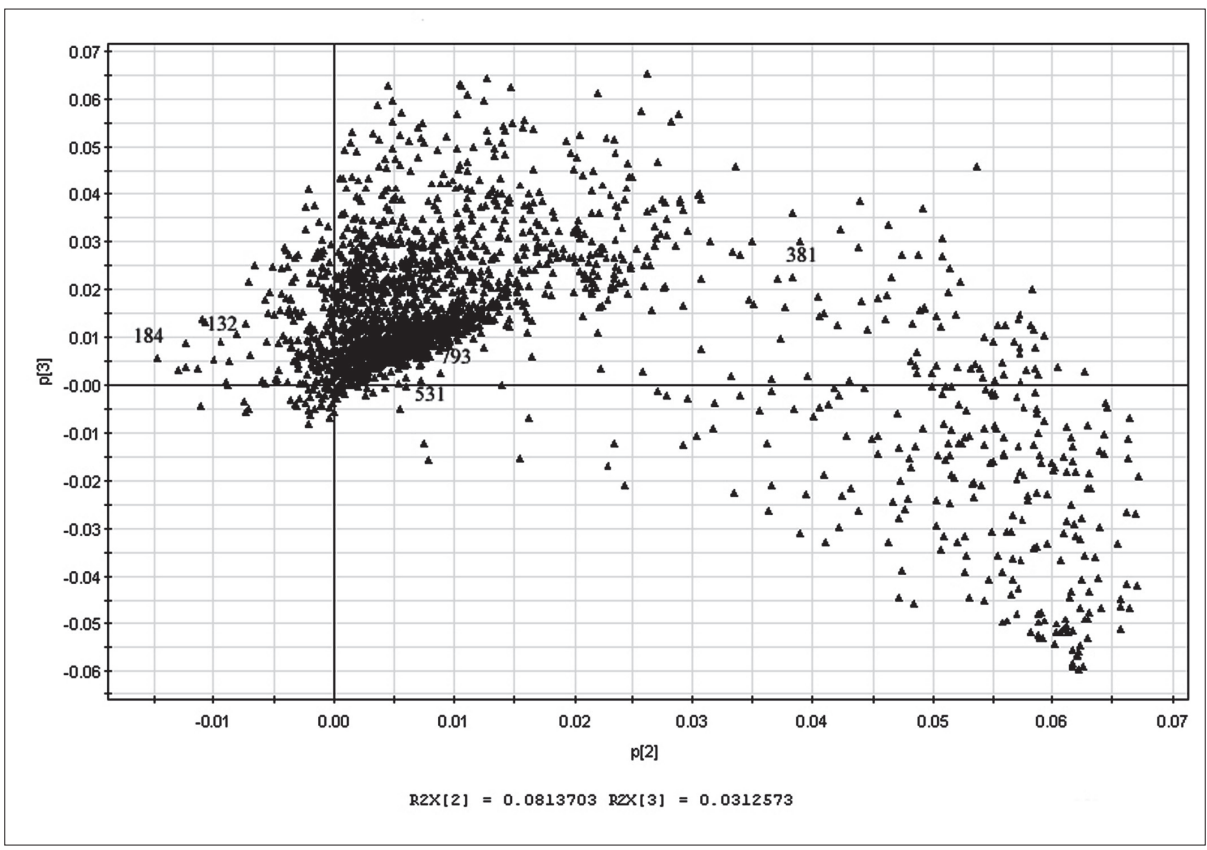

Figure 3 - PCA analysis of image from the analysis shown in figure 2. 


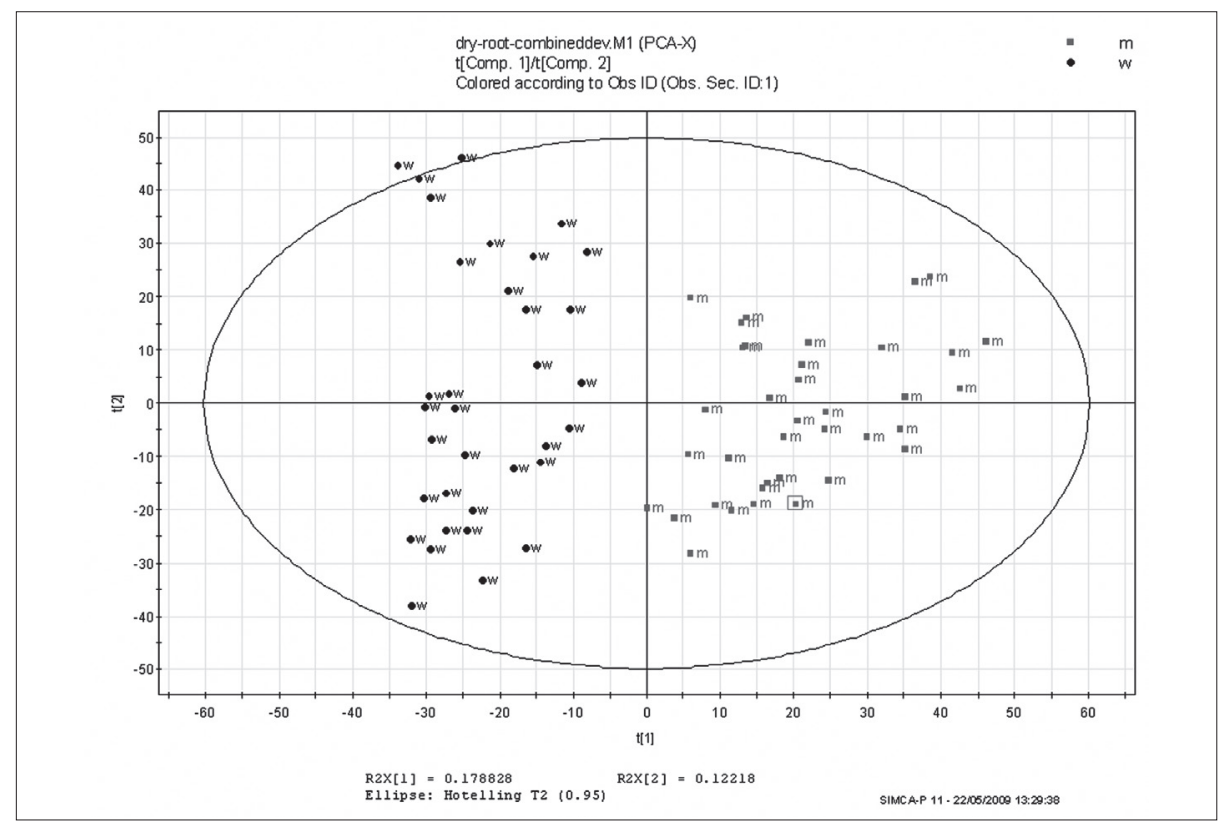

Figure 4 - PCA analysis of two images from roots of Arabidopsis thaliana.

The metabolic profiles obtained from the individual laser positions used to obtain an image of the two roots were used as separate data sets in the analysis. The roots from one sample were labeled $\mathrm{w}$ and those from the putative mutant root were labeled $\mathrm{m}$. 